\title{
Agnieszka Dauksza
}

\section{„Posłuchaj, jak mi prędko bije twoje serce". Afektywny potencjał poezji Wisławy Szymborskiej $^{1}$}

\begin{abstract}
"Listen how your heart pounds inside me". The Affective Potential of Wisława Szymborska's Poetry

The article is an attempt at an affective reading of poems by Wisława Szymborska, who was sensitive to poetic methods and strategies of building the mental fabric of poems, creating relations of intimacy, and accentuating the tensions, emotions and moods. The essence of the emotionalism of this poetry lies in the difference between affection and affectation. Some avant-garde inspirations of Szymborska are discussed. The author of the article proposes also to read this poetry in the context of Mikhail Bakhtin's category of "co-presence," termed by Tzvetan Todorov as "exotopy." Early poems by Szymborska are confronted with her later poetry, and the central meeting point are the empathy and mindfulness with which the poet treats the described characters. The author of the article focuses particularly on numerous references to the dead, who in Szymborska's poetry function as "figures of absence."
\end{abstract}

Słowa kluczowe: Szymborska Wisława, afekt, nieobecność, intymność, uważność

Keywords: Szymborska Wisława, affect, absence, intimacy, mindfulness

1 Autorka uzyskała środki w ramach finansowania stypendium doktorskiego z Narodowego Centrum Nauki, nr UMO-2016/20/T/HS2/00106. Początkowe fragmenty tekstu zostały wygłoszone podczas Międzynarodowego Festiwalu Wisławy Szymborskiej w Bolonii w $2016 \mathrm{r}$. 
Perspektywa afektywnego odczytania nie jest chyba w przypadku twórczości Wisławy Szymborskiej oczywista. Zwykło się bowiem przyjmować, że ekspresję tej autorki cechuje zintelektualizowanie, pewna powściągliwość, lakoniczność, „higieniczność”2, dyskrecja i „,emocjonalna dyscyplina”3. Rzecz nie jest jednak prosta i jeśli miałabym przystać na podobne tezy, to tylko przy zastrzeżeniu, że poezja Szymborskiej jest w tym samym stopniu intelektualna, w jakim uczuciowa. I od razu wypada stwierdzić, że nie chodzi tu o ckliwość czy nastrojowość, lecz o awangardowy w istocie prymat „dyscyplinowania” uczuć.

\section{Szukanie słowa}

Wbrew pozorom proponowane przez Jalu Kurka „kiełznanie” nie było tożsame z rugowaniem uczuć z literatury, ale miało służyć funkcjonalnemu „przemycaniu tzw. indywidualności”, które zamiast „odtwarzać serce” poety, pozwoli „stwarzać świat tekstu”4. Podobnie zresztą z postulowaną przez Thomasa S. Eliota „,bezosobową teorią poezji”, koniecznością depersonalizowania oraz infiltracji pozaestetycznych doświadczeń ${ }^{5}$. Według tej koncepcji obowiązkiem nowoczesnego twórcy jest umiejętne transponowanie doznań w kategorie umysłu i poszukiwanie adekwatnego ,słownego ekwiwalentu dla stanów intelektu i uczucia"'.

Dlaczego w tak ogromnym skrócie powołuję się na awangardowe dziedzictwo? Otóż, jakkolwiek zabrzmi to banalnie, jestem przekonana, że poetycka wrażliwość Szymborskiej została ukształtowana właśnie przez sztukę, literaturę i manifesty pierwszych awangardzistów. O ile jednak dla tamtych ucieczka od patosu, depersonalizacja czy konceptualne chwyty były wyrazem buńczucznego dystansowania się od tradycji, o tyle dla Szymborskiej podobne zabiegi stanowiły już samą podstawę wypowiedzi.

Ciekawie tę prawidłowość skomentował Artur Międzyrzecki, stwierdzając:

2 Mam tu na myśli choćby próby scharakteryzowania biograficzno-literackiego fenomenu Szymborskiej podejmowane m.in. przez Teresę Walas i Włodzimierza Maciąga [w:] A. Bikont, J. Szczęsna, Wisławy Szymborskiej pamiątkowe rupiecie, przyjaciele i sny, Warszawa 2003, s. 13-15.

3 J. Szczęsna, „Pisałam wiersze, piszę wiersze i mam zamiar pisać wiersze” [w:] W. Szymborska, Czarna piosenka, Kraków 2014.

4 J. Kurek, Zmierzch natchnienia, „Europa” 1930, nr 7.

5 T.S. Eliot, Tradycja i talent indywidualny [w:] Szkice literackie, red. W. Chwalewik, przeł. H. Pręczkowska, M. Żurowski, W. Chwalewik, Warszawa 1963.

6 T.S. Eliot, Poeci metafizyczni [w:] Szkice literackie, s. 48-49. 
Szymborska jest osobą o naturalnej dyskrecji, której coś takiego, jak postulat wstydu uczuć, głoszony z zapałem przez naszych kolegów z awangardy, musiał się wydać żenująco prostacki. Wstyd uczuć? Przecież to poetycka kondycja Wisławy.

Zgadzam się z diagnozą Międzyrzeckiego, jednak mam wrażenie, że w przypadku Szymborskiej nie chodziło o ,wstyd”, ale o niechęć przed nieuzasadnionym epatowaniem emocjami ${ }^{8}$. Stany afektywne jako takie stanowią bowiem centrum tekstowych światów Szymborskiej, choć faktycznie funkcjonują one na szczególnych prawach, o czym szerzej za chwilę.

Co więcej, Szymborska przyjmuje za Wiktorem Szkłowskim postulat odnowy poezji, ale robi to jakby na przekór, według specyficznych zasad. Zwykle nie jest dla niej priorytetem inwencja językowa i „wskrzeszanie słowa”, ale ważne są próby przywracania zdolności odczuwania rzeczy, opisywania ich, jak gdyby były widziane po raz pierwszy, oraz poszukiwania form wyrazu dla relacyjnego bycia w świecie ${ }^{9}$. Eksperymenty tekstowe inicjowane są przez koncept, który - jak się wydaje - dopiero pociąga za sobą wybory formalne. Istotne jest więc przede wszystkim napięcie między odczuciem czy wyobrażeniem zjawiska a zaskakującą perspektywą jego przedstawienia. Szymborska zwykle zwraca uwagę nie tyle na sam akt komunikacji, ile na dany fenomen; chce „dać rzeczy słowo” nie przez ekstrawagancję czy zawiłość wypowiedzi, lecz przez konceptualne ukazywanie zjawisk w nieoczekiwanych relacjach, rolach i zestawieniach, każdorazowy dobór najbardziej adekwatnej konwencji, gatunku i stylu. Poetka tworzy pokaźny rezerwuar przypadków, postaci, zwierząt, roślin i obiektów, rejestrując skalę możliwych form istnienia i usiłując przełożyć specyfikę tych zjawisk na język poetycki. Wbrew koncepcji Szkłowskiego istotą nie jest szokowanie czytelnika czy wytrącanie go z rutyny odbiorczej przez celowe komplikowanie przekazu. Jedną z bardziej charakte-

7 A. Bikont, J. Szczęsna, Wisławy Szymborskiej pamiątkowe rupiecie..., s. 14.

8 Na marginesie można dodać, że strategii artystycznej odpowiadała chyba kondycja osobowościowa poetki, czyli „geny plus wychowanie”, jak to lapidarnie określiła Teresa Walas. Włodzimierz Maciąg dodawał: „Szymborska uważa, że nie należy uzewnętrzniać emocji”. Paradoksalnie, nie bez znaczenia mogło być także formowanie poetki przez jej pierwszego „mecenasa”, ojca - Wincenta Szymborskiego, który płacił córce 20 groszy za napisany wiersz, ale pod warunkiem, że ten daleki był od zwierzeń i sentymentalnego tonu. Mówiąc o osobowości Szymborskiej, mam na myśli nie tylko osobiste przymioty, lecz także upodobania, niekiedy deklarowane w żartobliwym tonie w Lekturach nadobowiązowych. Przykładowo, dziennik pewnej francuskiej damy oczekującej ścięcia na szafocie Szymborska oceniała z uznaniem jako „obraz codziennej zwycięskiej walki, jaką toczyć musiała autorka z własną słabością, udrękami i lękiem. Nie to w nim najważniejsze, co wyraziły słowa, ale to, czego nie wyraziły. Czego autorka surowo sobie zabroniła, aby trzymać się prosto, aż do końca". W. Szymborska, Wszystkie lektury nadobowiązkowe, Kraków 2015, s. 472. Por. A. Bikont, J. Szczęsna, Wistawy Szymborskiej pamiątkowe rupiecie..., s. $12-16$.

9 W. Szkłowski, Wskrzeszenie słowa [w:] Rosyjska szkoła stylistyki. Wybór tekstów, red. M.R. Mayenowa, Z. Saloni, Warszawa 1970, s. 162-165. 
rystycznych cech tej poezji jest prostota, niekiedy wręcz pozorna ,,przezroczystość" języka.

$\mathrm{Na}$ proces kształtowania stylu niewątpliwie miały wpływ wojenne i tużpowojenne doświadczenia, na co zresztą pośrednio wskazują dwie przesłanki. Pierwsza, anegdotyczna, to historia pewnego listu nadesłanego do redakcji „Dziennika Literackiego”, w którym zarzucono wierszowi Szymborskiej „zawiłość” i „niezrozumiałość”, jakiej nie przyswoi ani „drwal z Komi”, ani „pastuch z Kazachstanu”. Mimo jawnie ideologicznego wydźwięku tamtej krytyki Szymborska zaprzestała pisania na prawie dwa lata ${ }^{10} \mathrm{i}$ - jak można dziś stwierdzić - odtąd konsekwentnie stosowała się do wymogu „zrozumiałości”.

Drugą przesłankę sugeruje utwór Szukam słowa z 1945 roku:

Chcę określić ich jednym wyrazem:

Jacy?

Biorę słowa potoczne, ze słowników kradnę,

mierzę, ważę i badam -

Żadne

nie odpowiada.

$[\ldots]$

Bezsilna nasza mowa,

jej dźwięki nagle - ubogie.

Szukam wysiłkiem myśli,

szukam tego słowa -

ale znaleźć nie mogę.

Nie mogę (CP, s. 28-29) ${ }^{11}$.

Ogólniejsze dla twórców tego czasu przeświadczenie o wyczerpaniu języka, niewyrażalności doświadczenia II wojny, niemożności i zarazem konieczności świadczenia zbiega się tu z potrzebą zrozumienia i opisu „ściślej i wyraźniej / kim byli oni - wszystko co się działo" oraz wprost werbalizowaną chęcią znalezienia słowa, które „pomieści w sobie każdą mogiłę zbiorową”. Wiersz - choć typowy dla patetycznej poetyki literatury powojennej - nie jest wcale charakterystyczny dla poezji Szymborskiej ze względu na ton wypowiedzi, retorykę silnych emocji (,straszliwy gniew”, „nienawiść wrząca”), perspektywę zbiorową („nasza mowa”) oraz nieironiczne użycie wielkich kwantyfikatorów (,wszystko, co się działo”, „każde słowo - tchórzliwe”).

10 Por. J. Szczęsna, „Pisałam wiersze, piszę wiersze i mam zamiar pisać wiersze” [w:] W. Szymborska, Czarna piosenka, s. 9.

11 Kolejne cytaty z utworów Wisławy Szymborskiej lokalizowane są następująco: Sto pociech, Warszawa 1967 - (SP); Wszelki wypadek, Warszawa 1972 - (WW); Wielka liczba, Warszawa 1976 - (WL); Ludzie na moście, Warszawa 1986 - (LM); Koniec i poczatek, Poznań 1993 - (KP); Chwila, Kraków 2002 - (C); Dwukropek, Kraków 2005 - (D); Zmyst udziału, Kraków 2006 - (ZU); Miłość szczęśliwa i inne wiersze, Kraków 2007 - (MS); Tutaj, Kraków 2009 - (T); Wystarczy, Kraków 2011 - (W); Czarna piosenka, Kraków 2014 $-(\mathrm{CP})$. 
Mimo wszystko da się w tym utworze rozpoznać zawiązki późniejszego stylu poetki, na co wskazują między innymi: uparta dążność do rozpoznania skali zjawiska, diagnozowanie jego ponadindywidualnego charakteru, próbowanie wielu wariantów opisu, zaangażowanie i jednocześnie świadomość odpowiedzialności za słowo mające upamiętniać ofiary i konsolidować wspólnotę żywych. Poczucie odpowiedzialności, które wynikało zapewne z oceny doświadczeń II wojny światowej, w zasadniczy sposób różniło się od zaangażowania poetów awangardy. Być może właśnie dlatego jeszcze w przeddzień fascynacji komunizmem Szymborska, choć ewidentnie uwewnętrzniła postulat inwencyjnego przedstawienia i emocjonalnej ,wstydliwości”, odrzuciła awangardową lekcję eksperymentatorstwa, decydując się na wyważoną potoczność. Prosty i klarowny przekaz miał umożliwiać egalitarny dostęp do poezji rejestrującej zmienny obraz powojennej rzeczywistości i przejście od „,świata”, który „umieliśmy kiedyś na wyrywki”, tak „łatwego”, „Zwykłego” i „małego, że się mieścił w uścisku dwu rąk”, do poznawania „,naszego łupu wojennego, którym jest wiedza o świecie” - ,wielkim”, „trudnym” i „dziwnym" (CP, s. 31).

Charakterystycznej, przystępnej dla odbiorców konwencji pisania odpowiada zresztą podejmowana przez Szymborską problematyka. Trudno niekiedy pozbyć się wrażenia, że jej wiersze - przekładane są na język krytyki - ocierają się o banał, a tendencja jest znamienna właściwie dla całego dorobku poetki. Wiele wskazuje, że jest w tym jakaś metoda, wszak ,nie ma pytań pilniejszych od pytań naiwnych" (MS, s. 274). Szymborska faktycznie rozważa najbardziej elementarne kwestie i bada przyziemne sprawy, traktując je tak, jak gdyby straciły oczywistość. Poetka, odrzucając kolejno prawa religijne oraz ideologiczne, decyduje się „wyznawać” wiarę w materię, szanować ją i opisywać rządzące nią mechanizmy. Jej perspektywa najbliższa jest świeckiemu materializmowi i wbrew pozorom nie ogranicza się do werbalizowanego na różne sposoby „zachwytu” i „zdumienia” wywoływanego przez realia. Nieodmiennie, choć nie zawsze wprost, wypunktowuje przejawy ludzkiego sprzeniewierzenia się naturze i wspólnocie, krytykuje „nieuwagę" (D, s. 33), egoizm i „niewiedzę niewiedzy” (W, s. 19), „niepamiętanie” (W, s. 17) oraz nieczułość. Jej poezja jest więc banalna o tyle, o ile można za banalne uznać elementarne prawa (współ)bycia w świecie.

\section{Zmysł udziału}

Z pewnością należy mieć na uwadze te zależności, podejmując się próby afektywnej lektury dorobku Szymborskiej. Afektywnej, to znaczy takiej, która wyczulona jest na metody i strategie tworzenia przez poetkę tkanki mentalnej utworów, budowania relacji intymności, akcentowania napięć i nastrojów, niekiedy również znaczącego wplatania wątków biograficznych w porządek tekstowy. Siłą rzeczy ten tryb interpretacji prowokuje także do jawnego lo- 
kowania pozycji odbiorczej; lub odwrotnie - niejednoznaczny stosunek do twórczości wymusza wrażeniową logikę opisu. Pewne jest, że w przypadku tej analizy punkt wyjścia stanowi kilka podstawowych pytań: czego przejawem jest niekiedy irytujacy, lecz ewidentnie celowy minimalizm, prostota, klarowność i powściągliwość przekazu? Jaki wpływ miał na twórczość Szymborskiej czas wojny? W jakim celu poetka metodycznie - być może wręcz obsesyjnie - rejestruje i kataloguje w swoich wierszach kolejne aspekty rzeczywistości? $\mathrm{Z}$ czego wynika fascynacja materią? Jaki jest charakter wewnątrztekstowych relacji i na czym polega dialogiczność tych wierszy?

Zgodnie ze współczesnymi badaniami z nurtu studiów afektywnych wyodrębniam tu afekt, uczucie i emocję jako nietożsame kategorie. Przyjmuję za czerpiącym z filozofii Gilles'a Deleuze'a Brianem Massumim, że afekt jest intensywnością, psychocielesną jakością odczuwaną przez jednostkę, lecz niekoniecznie przez nią uświadamianą ${ }^{12}$. Dopiero świadomy odbiór, choćby częściowe zdefiniowanie i „pomyślenie” tego stanu pozwala na wskazanie i nazwanie konkretnego uczucia. Emocje z kolei to stany wyższego rzędu, które jako takie są konwencjami odczuwania - stanowią bowiem rodzaj społecznej reprezentacji tego, co indywidualne i przedjęzykowe. W tym układzie emocje jawią się więc jako kulturowo zmienne, językowe konstrukty.

Korzystając z tego pobieżnie zarysowanego rozróżnienia, mogę stwierdzić, że Szymborska w swojej poezji - oprócz pierwszych, tużpowojennych tomów - pozostaje sceptyczna wobec emocji, zwłaszcza tych wielkich i zbiorowych. To, co najważniejsze w jej twórczości rozgrywa się na nieco „niższym poziomie", w napięciu między afektywnością a uczuciowością. Pokuszę się tymczasem o szkicowe rozróżnienie dwóch podstawowych metod ekspresji Szymborskiej.

Stany uczuciowe są często „zapalnikami” wierszy tej autorki. Nieoczywistość polega na przyjmowaniu coraz to nowych perspektyw nadawczych oraz na umiejętnym dystansowaniu się od wrażeń. Opisany przez Wojciecha Ligęzę bogaty repertuar formalnych chwytów Szymborskiej nieodzownie służy do przyjmowania kolejnych masek, wcielania się w role, ironizowania, hiperbolizowania czy karykaturyzowania ${ }^{13}$. Opanowanym do perfekcji sposobem jest rzutowanie jednostkowych uczuć na inne postaci i obiekty. Dzieje się tak na przykład w Kocie w pustym mieszkaniu, gdzie żal po śmierci bliskiej osoby przypisany zostaje osamotnionemu zwierzęciu ${ }^{14}$. Cierpienie i smutek bywają także rzutowane na krajobrazy, jak choćby w wierszu Chmury, czy na przedmioty nieożywione, na przykład w utworach Negatyw i Stuchawka:

12 B. Massumi, Autonomia afektu, przeł. A. Lipszyc, „Teksty Drugie” 2013, nr 6.

13 W. Ligęza, O poezji Wistawy Szymborskiej. Świat w stanie korekty, Kraków 2002.

14 O strategii unikania pierwszoosobowej perspektywy por. L. Neuger, $W$ otchłani. Próba lektury „Końca i początku” Wisławy Szymborskiej [w:] idem, Pomysty do interpretacji. Studia o literaturze polskiej, Kraków 1997, s. 83-89. 
Śni mi się pewność,

że dzwoni do mnie umarły

[...]

słuchawka

nie taka jak była,

stała się ciężka,

jakby do czegoś przywarła,

w coś wrosła,

coś oplotła korzeniami.

Musiałabym ją wyrwać

razem z całą Ziemią (C, s. 13).

Podwójny ruch kiełznania i werbalizowania jakości uczuciowych jest swoistym „mówieniem mimo wszystko”. Pozorna lekkość konceptów nie osłabia jednak faktycznego wydźwięku tej poezji. Wiersze Szymborskiej są zwykle potrójnie kodowane - na poziomie odbioru literalnego, erudycyjno-kompetencyjnego oraz odczuciowego. Niemożność oddzielenia tych aspektów przy jednoczesnym poczuciu ich dysonansowości decyduje o sile oddziaływania utworu. Uświadomienie sobie niewspółmierności między tym, kto i jak mówi, oraz tym, o czym faktycznie jest mowa, bywa źródłem najwyższych poruszeń czytelniczych. Wspomniany Kot w pustym mieszkaniu jest niewątpliwie jednym z mocniejszych przykładów takiej sprawczości tekstu.

Trzeba jednak uczciwie zaznaczyć, że zdarzają się odstępstwa od tej reguły. Pozostając w obszarze utworów elegijnych, chciałabym zwrócić szczególną uwagę na Pożegnanie widoku, które uważam za jedno z najintymniejszych wyznań w dorobku Szymborskiej. Tym razem poetka rezygnuje z maskowania pozycji, wyrafinowanie „mówienia mimo wszystko” polega nie na dystansowaniu się czy rzutowaniu uczuć na inne obiekty, lecz zawiera się w sposobie eksponowania głosu kobiety opłakującej mężczyznę. Napięcie budowane jest przez cyklicznie powracające deklaracje zaprzeczające odruchowym reakcjom: „Nie mam żalu do wiosny, / że znowu nastała”, „,Rozumiem, że mój smutek / nie wstrzyma zieleni”, „Nie mam urazy / do widoku o widok” (KP, s. 22). Świadomość nikłości jednostkowych uczuć wobec skali wydarzającego się świata idzie w parze z poczuciem niemożności wyrażenia tego, jak wiele się czuje.

Odmawianie racji kolejnym emocjom - zasadnym w sytuacji żałoby - wynika zapewne z trudności przypisania swoich odczuć konkretnym, nazywalnym jakościom. Zwykła nie-czułość ze strony otaczających realiów skłania mówiącą kobietę do aktu solidarności z umarłym:

Na jedno się nie godzę.

Na swój powrót tam.

Przywilej obecności -

rezygnuję z niego.

Na tyle Cię przeżyłam

i tylko na tyle,

żeby myśleć z daleka (KP, s. 23). 
Wiersz nie jest pożegnaniem z tym, który odszedł, lecz jest zwrotem ku niemu w geście wspólnego „pożegnania widoku” nadto kojarzącego się z życiem. Jednocześnie żal, smutek, ból, uraza i tęsknota okazują się słabsze niż „miłość mocna jak śmierć”" odwrót od bieżącego życia i zwrot ku wspomnieniowej bliskości.

Zdarza się, że poetka jest zbolałą lub przestraszoną, a niekiedy zrozpaczoną obserwatorką, niemającym złudzeń świadkiem wydarzeń. Jednak smutek, strach czy niepewność równoważone są zwykle przez rozpatrywanie własnej kondycji w perspektywie ponadjednostkowej, ponadgatunkowej czy wręcz globalnej. Szymborska w takich wierszach, jak Przemówienie w biurze znalezionych rzeczy, Zdumienie czy Urodziny dostrzega różnorodność form życia i biologiczną ciągłość istnienia, co - z jednej strony - pozwala przywracać ludzkim sprawom właściwą miarę, a z drugiej - zyskiwać uważność wobec tego, co nieludzkie ${ }^{16}$.

Rozpatrywana pod tym kątem poezja Szymborskiej bywa świadectwem wyniszczania dziedzictwa natury i przemijania kolejnych form oraz gatunków, do czego z nieznającym litości zacięciem przyczynia się człowiek. Autorka wypunktowuje te winy; na przykład w wierszu Tarsjusz:

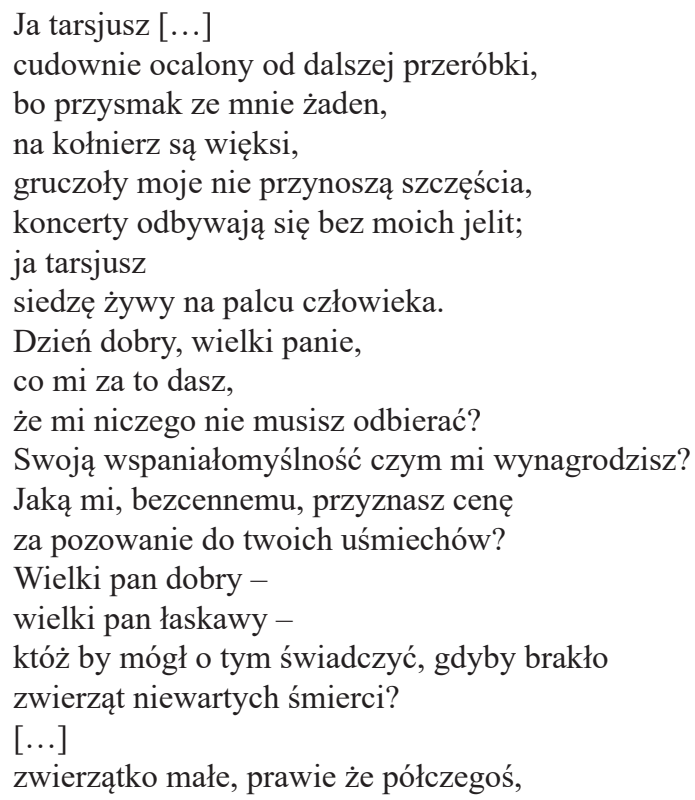

15 Nawiązuję do sformułowania użytego przez Agatę Bielik-Robson, por. eadem, Miłość mocna jak śmierć. Przyczynek do innej filozofii skończoności, „Teksty Drugie” 2013, nr 6 .

16 Nie sposób rozwinąć tutaj tego wątku, jednak o relacjach ludzkiego i zwierzęcego, także o zwierzęcych „ciałach nieskończonych możliwości”, piszę szerzej w „Tekstach Drugich" 2010, nr 5. 
co jednak jest całością od innych nie gorszą;

tak lekki, że gałązki wznoszą się pode mną

i mogłyby mnie dawno w niebo wziąć,

gdybym nie musiał raz po raz

spadać kamieniem z serc

ach, roztkliwionych;

ja tarsjusz

wiem, jak bardzo trzeba być tarsjuszem (Tarsjusz, SP, s. 47-48).

Perspektywa pojedynczego ocalonego, jaką przypisuje tarsjuszowi Szymborska, ma świadczyć o skali przemocy zadawanej innym gatunkom - zabijanym, wykorzystywanym i przerabianym na ludzkie potrzeby czy dla wygody lub rozrywki. Tarsjuszowe istnienie, owo „półczegoś”, „złożone z dwóch źrenic i tylko bardzo już koniecznej reszty", ocalało, gdyż jest nieznaczące z merkantylnego punktu widzenia. Autorka w gorzko-ironicznej, a w istocie dramatycznej przemowie tarsjusza obnaża cynizm i ekonomiczną bezwzględność ludzi, ale także ich pozorowaną etyczność oraz fałszywą empatię. Szymborska nie pozwala na roztkliwienie, wczucie nie jest możliwe - rozsądnie używa „zmysłu udziału”, próbując zbliżyć się i zrozumieć to, co odmienne, ale też stale zachowuje dystans „niewspółobecności”. Ma świadomość nieprzekładalności postaw oraz nietożsamości perspektyw ludzkiej i zwierzęcej, co zresztą dobitnie oddaje tautologiczna pointa utworu: ,ja tarsjusz / wiem, jak bardzo trzeba być tarsjuszem".

Uważność Szymborskiej to zatem także otwartość pozbawiona chęci zawłaszczenia drugiego obiektu. Poetka zdaje się nie ustawać w bezinteresownym zaciekawieniu ,życiem nie do pojęcia” (WL, s. 46), już w jednym z debiutanckich utworów pisze: „to ze zdumienia / wstaje potrzeba słów / i oto każdy wiersz / na imię ma zdumienie" (CP, s. 61). Ponawiane przez Szymborską wysiłki konceptualnego oddania słowami odczucia i oglądu innych bytów mogą być podejmowane dzięki uwrażliwieniu i uważności, jednak zawsze ograniczają je ramy ludzkiego poznania - wszak, jak wiadomo, człowiek „ma zaledwie zamysł zmysłu udziału [...], ledwie jego zawiązek, wyobraźnię" (ZU, s. 9). W takich wierszach, jak Milczenie roślin, Cebula, Tarsjusz, Widok z ziarnkiem piasku czy Rozmowa z kamieniem, autorka dopuszcza do głosu własne wyobrażenie perspektywy roślin, zwierząt i form nieorganicznych, nie tyle zakładając istnienie wspólnoty doświadczeń, ile właśnie projektując tryb ich funkcjonowania i pamiętając, że „to tylko nasze porównania. Zmyślona postać [...], a wiadomość nieludzka" (ZU, s. 30). Zmysł udziału - choć cenny - nie jest tożsamy z udziałem.

\section{Niewspółobecność}

Można rozpatrywać projekt antropologiczno-artystyczny Szymborskiej przez pryzmat Bachtinowskiej kategorii niewspółobecności, przez Tzvetana Todo- 
rova określanej jako egzotopia ${ }^{17}$. W koncepcji Michaiła Bachtina funkcjonuje schemat „wychodzenia poza siebie”, czyli - w wielkim uproszczeniu - podwójnego ruchu zachodzącego między procesami identyfikacji czy wczucia odbiorcy i jego dystansowania od przedstawianego świata. Mechanizm łączy procesy psychosomatycznego doświadczenia i aktywności percepcyjno-estetycznej. Dzięki niemu możliwe jest nie tylko rozumienie siebie i twórcza ekspresja, lecz także pojmowanie tego, co zewnętrzne i odmienne ${ }^{18}$.

Uważność Szymborskiej wobec realiów prowokuje do „bycia na zewnątrz siebie", wsłuchiwania się w głosy, odpominania przeszłości, rekonstruowania wydarzeń, podążania nowymi ścieżkami, badania i mnożenia perspektyw. Postaci z tekstów Szymborskiej wciąż na nowo przekraczają siebie, nie mogąc nadziwić się otoczeniu, przyzwyczaić do kształtu zjawisk i zrozumieć przemijalności form. Niewspółobecność objawia się m.in. przez lirykę roli i maski, ironię, wyliczenia oraz enumeracje, przybieranie naiwnego punktu widzenia, stylizacje itd. Jeśli uznać dane chwyty formalne za swoiste „pogonie” tropami różnorakich bytów lub kamuflaże, przeobrażenia i metamorfozy, wówczas „powroty" następowałyby wraz ze świadomym, wzbogaconym o nowe wrażenia, wyraźnie odczuwanym odnalezieniem się tu i teraz, w „pojedynczej osobie w ludzkim chwilowo rodzaju" (WW, s. 27). Odmienność i poszczególność, ku którym zwraca się poetka, nie są personifikowane wyłącznie przez samotnych (W przytutku), chorych (Spacer wskrzeszonego), bezbronnych (Powroty) czy niedocenionych (Klasyk). Autorka troszczy się także o to, co pozaludzkie i nie-ludzkie, zwierzęce i przedmiotowe, co słychać choćby w na poły żartobliwym pytaniu: „Tyle naraz świata ze wszystkich stron świata [...]. Jak ma się w to bawić osoba żyjąca?" (WW, s. 29).

Niewspółobecność przejawia się w tej poezji również w relacji z bliskim człowiekiem i nieczęstej umiejętności bycia, a nie zawłaszczania. Mistrzostwo egzotopicznego przekroczenia własnej perspektywy poznawczej Szymborska osiąga we Wszelkim wypadku:

Ocalałeś, bo byłeś pierwszy.

Ocalałeś, bo byłeś ostatni. [...]

Więc jesteś? Prosto z uchylonej jeszcze chwili?

Sieć była jednooka, a ty przez to oko?

Nie umiem się nadziwić, namilczeć się temu.

Posłuchaj,

jak mi prędko bije twoje serce (WW, s. 6).

W interpretacji tego wiersza Stanisław Balbus zwraca uwagę na potoczny, konwersacyjny charakter zwrotów wskazujących na typowość i powszedniość przedstawionej sytuacji, ale też sygnalizujących „ukryty dialog” z bliską oso-

17 T. Todorov, Antropologia filozoficzna, przeł. J. Stankiewicz [w:] M. Bachtin, Dialog, język, literatura, red. E. Czaplejewicz, E. Kasperski, Warszawa 1983, s. 462-465.

18 M. Bachtin, Kierować się odwaga [w:] idem, Dialog, język, literatura, s. 370. 
bą, „która przed chwilą cudem uratowała się z wypadku”"19. Choć zgadzam się z tymi rozpoznaniami badacza, zastanawiają mnie finalne tezy wywodu:

[...] autorka utożsamia się $\mathrm{z}$ ocalonym bohaterem wydarzenia. Jej westchnienie ulgi: „zdarzyło się nie tobie” odnosi się zarówno do partnera dialogu, jak i do niej samej. Stawia się w jego sytuacji, zamienia się miejscami. Przeżywa los cudzy jako swój własny, wie bowiem, że los ten w każdej chwili (,później, bliżej, dalej”) może stać się jej udziałem ${ }^{20}$.

W przeciwieństwie do Balbusa nie upatruję w postawie kobiety utożsamienia się z ocalonym, które byłoby oparte na poczuciu ulgi pomieszanej z obawą o własne losy. Przeciwnie - gdy enumeracja wykluczających się okoliczności warunkujących ocalenie przerwana zostaje prostym „więc jesteś?”, dochodzi do przekroczenia typowo ludzkiej, egocentrycznej perspektywy. Początkowe partie wiersza można uznać za paniczną gonitwę myśli kogoś, kto bardzo zaniepokojony, wręcz przerażony rozwojem wypadków, wciąż wątpi w bezpieczeństwo dopiero (i czy aby na pewno?) ocalałego. Pytanie „więc jesteś?” zmienia porządek wywodu i ustanawia relację największej intymności. Kobieta „przekracza” siebie, swoją perspektywę myślenia i odczuwania, z trudem uspokaja bieg myśli i opanowuje chaos wyobrażeń, po czym zwraca się ku bliskiej osobie. W pytaniu „więc jesteś?” zawierają się jednocześnie pogłos lęku, wyobrażeniowy powidok najgorszego, ale też niepewność i niedowierzanie powoli przeradzające się w ulgę i afirmację.

Poczucie, o którym pisze Szymborska, jest w istocie afekcją. Jak słusznie przypomina Ryszard Nycz:

[...] dawna polszczyzna odróżniała, oprócz afektu, ,afekcję”, czyli skłonność ku komuś, czemuś (w słowniku Arcta mamy jeszcze w tym sensie „afekcjonować” mieć upodobanie do czegoś, sprzyjać), od ,afektacji” - przesady, udawania afektu. We współczesnej polszczyźnie niestety to drugie znaczenie wyparło i zastąpiło pierwsze - ze szkodą i dla samej rzeczy, i dla mówienia o niej ${ }^{21}$.

Jednocześnie „Zwrócona na zewnątrz” skłonność ku czemuś lub komuś jest otwarciem na odmienność, rezygnacją z relacji zawłaszczenia, pozwoleniem na bycie. Właśnie w różnicy między afekcją a afektacją zdaje się zawierać istota afektywności poezji Szymborskiej. Znamienne dla tych wierszy otwarcie na różnorodność zjawisk, przejawiające się w trosce i uważnym zaciekawieniu, sygnalizowane jest zwykle w prostych, lakonicznych stwierdzeniach, dalekich od wszelkiej przesady i afektacji właśnie.

Kunszt budowania podobnych wyznań uwidacznia się także w finale Wszelkiego wypadku:

19 S. Balbus, Wszelki wypadek [w:] Radość czytania Szymborskiej. Wybór tekstów krytycznych, red. S. Balbus, D. Wojda, Kraków 1996, s. 345.

20 Ibidem.

${ }_{21}$ R. Nycz, Afektywne manifesty, „Teksty Drugie” 2014, nr 1, s. 10. 
Nie umiem się nadziwić, namilczeć się temu.

Posłuchaj,

jak mi prędko bije twoje serce (WW, s. 6).

Ewidentnie próby racjonalizacji i werbalizacji kończą się fiaskiem, cudze przeżycie nie mieści się w słowach. Szymborska skłania się więc ku wrażeniom, pozornie audialnym, jednak w istocie przede wszystkim dotykowym. Relacja faktycznej bliskości i zażyłości opiera się ostatecznie na prymarnym czuciu i odczuwaniu. Dochodzi do maksymalnego uproszczenia banalnych zwrotów typu: „oddać komuś serce”. Afekcję wyraża się w odruchowym przyspieszeniu pracy serca i zamianie zaimków. Tylko tyle i aż tyle. Trudno mówić w tym przypadku o empatii, chodzi raczej o egzotopiczną wspólnotę. Widmo tego, „co zdarzyć się mogło” znowu, chociaż na chwilę, ustępuje sile „uścisku przedawnionej śmierci” (SP, s. 20).

Jak starałam się pokrótce ukazać, praktykowanie figury niewspółobecności - tak typowe dla poetyki Szymborskiej - obejmuje większość opisanych w tym dorobku relacji - ludzko-ludzkich, ludzko-zwierzęcych, ludzko-roślinnych i ludzko-przedmiotowych, gdzie przekroczenie własnej wsobności, uwrażliwienie i ruch zachodzący od siebie do innego, zbiega się automatycznie z zachowaniem dystansu, poszanowaniem odrębności. Przypadki, które są wyłomem od tej zasady, to z reguły krytyka nadużyć, zawłaszczeń, obojętności lub wyrachowania, na co wskazują m.in. wiersze: Na wieży Babel, Perspektywa i Glosy. Bywa także, iż autorka w celu wzmocnienia wydźwięku rozważanego problemu pozoruje egzotopię, czyniąc próbę zrozumienia cudzej, radykalnie odmiennej perspektywy głównym konceptem utworu, jak na przykład w wierszach Terrorysta, on patrzy lub Zamachowcy.

Nietrudno zauważyć, że dotychczas rozważane przykłady niewspółobecności dotyczyły zróżnicowanych postaci i wytworów materii - w jakiś sposób dotykalnych, postrzeganych zmysłowo, możliwych do bezpośredniego odniesienia się oraz zaistnienia reakcji i relacji afektywnej. Słowem - były to postaci obecne. Nie wyczerpują one jednak repertuaru opisywanych przypadków. Szymborska z zastanawiającą konsekwencją i gorliwością podejmuje bowiem namysł nad umarłymi.

\section{„Mój umarły”}

Trzeba na wstępie stwierdzić: śmierć nie jest w tej twórczości jednoznaczna $\mathrm{z}$ nieobecnością. Jest nią naznaczona, to prawda, ale nigdy nie da się sprowadzić do pustki, braku czy nicości. Szymborska mnoży odcienie i tony „niebycia", a jej poezja - jak się okazuje - to także badanie form nieobecności. Nie chodzi tu oczywiście o poetyckie wywoływanie duchów, ale o reprezentowanie umarłych czy - zgodnie z określeniem Mirona Białoszewskiego - ,szukanie form dojścia”. Pojawia się kilka wierszy upamiętniających dane osoby, 
pisanych nie tyle ku czci i nie tyle „z powodu” ich śmierci, ile z ewidentnej fascynacji tym, co w nich żywe - np. W bialy dzień, gdzie mowa o Krzysztofie Kamilu Baczyńskim, Autotomia dedykowana pamięci Haliny Poświatowskiej, Tomasz Mann, Nieczytanie jako wyraz uznania dla Marcela Prousta, $W d y l i-$ żansie o Juliuszu Słowackim czy Ella w niebie upamiętniająca Ellę Fitzgerald.

Bywa także, iż pojawia się wspomnienie osób, które nie są przywoływane z imienia i nazwiska, ale mimo wszystko można domyśleć się ich zbiorowej tożsamości - zwłaszcza wtedy, gdy są tak zwanymi anonimowymi ofiarami ludobójstw czy katastrof. Dzieje się tak na przykład w wierszach Transport Żydów, Jeszcze czy Fotografia z 11 września. Szymborska podejmuje wówczas wysiłek upamiętnienia zmarłych, ,łowiąc to, co zatopione w zwierciadle niepamięci” (T, s. 9), lub opisując, „nie dodając ostatniego zdania” i dzięki temu ,powstrzymując ich przy życiu” (T, s. 35).

Jednakże znacznie więcej jest w tej twórczości momentów mniej jednoznacznych, gdzie wyczuwa się niepewność co do statusu wspominanych postaci - zarówno na poziomie odbiorczym, gdy czytelnik próbuje rozstrzygnąć, kim są przywoływani nieobecni - jak i na poziomie wewnątrztekstowym, gdy poetka uparcie docieka tego, co jest „poza zasięgiem naszej obecności” (SP, s. 17). Tę „kategorię” nieobecnych Szymborska określa lakonicznie mianem „moi umarli” (T, s. 15) lub „bliscy umarli” (W, s. 14). Na wciąż aktualną i aktualizowaną w poezji i przez poezję zażyłość wskazuje zresztą nie tylko częstotliwość przywoływania tych postaci, ale też tryb ich funkcjonowania oraz rola, którą - jak twierdzę - odegrali w kształtowaniu systemu wyobrażeń i poetyki Szymborskiej.

By zrozumieć arcyistotną dla omawianego dorobku prawidłowość, należy wrócić do opublikowanych niedawno juweniliów poetki i jej powinowactwa z awangardą. Właściwy debiut Szymborskiej, czyli zbiór wierszy z lat czterdzistych, który pod tytułem Czarna piosenka ukazał się dopiero w roku 2014, na pierwszy rzut oka jest zupełnie niepozorny. Choć jego autorka głosi niechęć do patetycznych form (,Żaden patos. Żaden nastrój. Żaden liryzm” (CP, s. 52)), to jednak właśnie one dominują w jej wypowiedzi. Mowa stale o nienawiści, rozpaczy, gniewie, utraconym szczęściu, żalu i tęsknocie. Dopóki w akcie lektury figury te wydają się typowymi, „uniwersalnymi” środkami powielanymi nagminnie przez poetów wojny i powojnia, odbiorca ma wrażenie, że zbiór debiutanckich wierszy nie rzutuje w sposób istotny na ocenę późniejszej twórczości (choć - trzeba przyznać - wyróżnia się tu godna osobnej refleksji zindywidualizowana, kobieca, pacyfistyczna perspektywa nadawcza, z której poetka orzeka o okupacji). Rzecz komplikuje się jednak wraz ze stopniowym dostrzeganiem we wczesnych wierszach przebłysków „późniejszej” Szymborskiej - dzieje się tak na przykład w utworach: $Z$ autobiografii dnia, Wymiary, List na Zachód, Janko Muzykant, Transport Żydów, Dedykowane poezji czy Szycie sztandaru. Chodzi zwykle o ,nieznane a znajome" (CP, s. 36) rozproszone obrazy, pojedyncze motywy, ciągi metafor, które tonem i stylem przypominają dobrze znane utwory autorki. Można by przejść 
nad nimi do porządku dziennego, uznać je za „echa”, a w istocie zapowiedzi, swoisty rezerwuar wielu późniejszych pomysłów ${ }^{22}$. Jednakże zwraca uwagę kontekst ich pojawiania się - ten generalny, wojenny, ale też indywidualny, wręcz intymny.

Gdyby pokusić się o pytanie, o czym właściwie jest tom Czarna piosenka, odpowiedź byłaby aż nadto prosta: o młodej kobiecie rozpamiętującej równie młodego mężczyznę, który niespodziewanie stał się jedną z ofiar wojennych; o kobiecie próbującej oswoić nagłą, trudną i dziwną nieobecność. Wspomnienie jego odejścia pojawia się w wierszu Janko Muzykant, który dedykowany został „pamięci poległego":

Odwracam głowę

i śmiesznie krzyczę w twe zdumione oczy,

w zakłopotaną linię ust -

że wiem, że pójdziesz.

$[\ldots]$

Tchem pytam:

Wrócisz?... Jutro?...

Czas pożegnania pisze świeca

sznurkiem woskowych łez.

Twój wielki, aż po sufit cień

ręką unosi gest

i salutuje:

Wrócę. JUTRO (CP, s. 32-33).

Kim był, jak się nazywał, dokąd wyjechał i dlaczego nie wrócił - na te pytania poezja Szymborskiej nie odpowiada. Więcej zdradza autorka w jednym z wywiadów. Wyznaje wówczas:

On pojechał do Wilna z ramienia AK. To był 1943, może 1944 rok. A potem żaden list nie przychodził. Dowiadywałam się, szukałam, ale nie natrafiłam nigdy na żaden ślad, nie dowiedziałam się, gdzie spoczywa ${ }^{23}$.

Z kolei faktograficzna lakoniczność tego wspomnienia znajduje rozwinięcie w uczuciowości tomu Czarna piosenka. Szymborska zapisuje wszystkie fazy procesu żałoby. Kolejno pojawia się niedowierzanie: „Lecz dopóki zapatrzony czekasz, dopóki czuwasz zasłuchany - czas o powrocie myśleć twoim”

22 O debiutanckich wierszach Szymborskiej rozpatrywanych jako tworzywo późniejszych pomysłów pisali m.in.: Wojciech Ligęza, O poezji Wisławy Szymborskiej. Świat...; Jacek Łukasiewicz, Wiersz wewnątrz gazety, „Teksty Drugie” 1991, nr 4; Tadeusz Nyczek, 22 x Szymborska, Poznań 1997; Anna Legeżyńska, Wisława Szymborska. Czytani dzisiaj, Poznań 2010; Anna Zarzycka, Rewolucja Szymborskiej 1945-1947. O wczesnej twórczości na tle epoki, Poznań 2010; Joanna Szczęsna, „Pisałam wiersze, piszę wiersze i mam zamiar pisać wiersze" [w:] W. Szymborska, Czarna piosenka; Paulina Małochleb, Świat po bajce jest siny, czyli Szymborska po wojnie, http:/www.ksiazkinaostro.pl/swiat-bajce-siny-czyli-szymborska-wojnie/ [dostęp: 21.02.2017].

23 A. Bikont, J. Szczęsna, Wistawy Szymborskiej pamiątkowe rupiecie..., s. 66. 
(CP, s. 49), wściekłość: „Mam w rękach siłę nienawiści, mam gniew zawęźlony w krtani”, niezgoda: „Nieśmiała, młoda, lepka zieleń liści. Chciałabym zrywać, deptać, ranič”, rozpacz: „Na grób, który może być wszędzie, pęki nie ściętych kwiatów. Nie wolno deptać ziemi. Grzech”, pokora: „może się prośba moja ziści. Będę się modlić o twój powrót do wszystkich bogów świata", żal: „Jesteś mą troską: wewnątrz ciemny. I żalem moim: już nieznany” (CP, s. 49), i wreszcie, w wierszu Zaduszki, wyciszenie: „Już tylko smutkiem szukam, z dawna znajomym światu: - gdzie?” oraz pogodzenie: „Nie przyszłam tutaj po żal. [...] Nie jestem tutaj po bunt [...], ale by znaleźć, chwycić, przygarnąć. Żyć" (CP, s. 55).

Pogodzenie i dalsze życie nie oznacza jednak zapomnienia - bohaterka Szymborskiej nieustannie zwraca się do bliskiego umarłego, prowadzi z nim dialog, przywołuje go, opowiada o tym, jak pod jego nieobecność „u nas życie się dopełnia" $i$,świat się dopełnia” (CP, s. 50). Wyraźnie poszukuje adekwatnych sposobów nie tyle diagnozowania braku, ile reprezentowania, uobecniania tego, który odszedł, oraz świadczenia o własnych uczuciach, które także traktowane są jako ślady jego obecności. Perspektywa kobiety zostaje trwale zapośredniczona stratą:

Podwójne życie: życie i ty.

Podwójna śmierć: śmierć i ja.

Podwójna pustka: ty - twój syn,

którego nigdy nie urodzę (CP, s. 67).

Szymborska nie może zrozumieć nieobecności, więc oswaja ją przez wyobrażanie sobie perspektywy umarłego. Właśnie wówczas - zapewne pierwszy raz w jej twórczości - zastosowana zostaje figura niewspółobecności. „Jej poległy” staje się wcieleniem radykalnej odmienności, która jest „,blisko-daleka”, ,już nieznana”, mimo podejmowanych prób pozostaje obca, trudna do przeniknięcia. Możliwe są ,tylko nasze porównania”, projektowany obiekt pozostaje osobny. W tym przypadku egzotopia ma ułatwić karkołomne próby pomyślenia i poczucia tego, co może dziać się z utraconym ukochanym, którego wypatruje bohaterka - na przykład w cyklu $Z$ autobiografii dnia:

Gdy mija, staje - ależ na pewno -

wiem.

Ten profil mi wiadomy, ten spadek ramion znam.

Mogę go jak z pamięci powtórzyć taśmą wystaw

na wylustrzonym chłodnym

szkle.

[...]

Idziesz ulicą Każdą, jesteś na placu Wszędzie.

Ssiesz w płuca tytoń mokry.

Dym rudy - rudy płaszcz.

Nim skręcisz w ulicę żadną, 
nim będzie nigdzie,

chwycę za guzik,

pytanie chuchnę w twarz:

Obywatelu Z Brudną Szyją, stań!

Posłuchaj, powiedz mi...

- nie ma-(CP, s. 39-40).

Uświadomienie sobie statusu bohatera, a niekiedy też adresata debiutanckich wierszy wymusza zwrócenie się na nowo ku tomom kolejnym, skonfrontowanie tego, co wspólne i podobnie brzmiące, porównanie nieznanych dotąd debiutanckich ,zapowiedzi” oraz dobrze rozpoznawalnych „ech”, wypunktowanie „podobieństw” oraz „różnic”. Nie chodzi bynajmniej o historycznoliteracką buchalterię czy wypominanie Szymborskiej zapożyczeń w tej „wczesnej” twórczości. Sprawa wydaje się znacznie bardziej interesująca i ukazuje chyba nierozpoznany dotychczas ciąg zależności między tak charakterystycznymi motywami, jak uważność, zmysł udziału, powściągliwość, imperatyw pamiętania, poszanowanie dla materii, tendencja do ciągłej zmiany perspektyw oraz niewspółobecność.

\section{Figury nieobecności}

Szymborska - pytana przez Annę Bikont i Joannę Szczęsną o swoje „niepisanie" o wojnie - twierdziła:

Trudno w poezji o sprawiedliwie wymierzone proporcje. Pisałam więcej, ale wiersze szły do kosza. Nigdy nie dorównałabym tu Różewiczowi czy Herbertowi, w ich poezji myśl o poległych jest obecna i twórcza do dziś. Czytając ich, zrozumiałam, że wyrazili swoje doświadczenia w sposób niezrównany. Nie potrafiłabym nic do tego dodać ani lepiej ująććc

Poetka faktycznie - zamiast pisać o poległych - pisze o jednym poległym. Choćby w wierszu Sen z tomu Sól z roku 1962, który stanowi chyba najbardziej ewidentne nawiązanie do tematyki debiutanckich wierszy:

Mój poległy, mój w proch obrócony, mój ziemia,

[...]

Wędruje przez ciemności od nigdy zagasłe, przez pustki otworzone ku sobie na zawsze, przez siedem razy siedem razy siedem cisz.

Zjawia się na wewnętrznej stronie moich powiek, na tym jedynym dostępnym mu świecie.

Bije mu serce przestrzelone (MS, s. 33).

Jest zapewne wiele przyczyn „ukrywania” czy zacierania doświadczenia wojny oraz tęsknoty za „bliskimi umarłymi” w poezji Szymborskiej, ale

24 Ibidem, s. 67. 
niewątpliwie istotny był wpływ awangardowego postulatu dyskrecji, wstydliwości uczuć, „filtrowania” tego, co intymne i uniwersalizowania sytuacji nadawczej. W konsekwencji poetka wypowiada się „o śmierci bez przesady”, czyli próbując przekroczyć typowy dla tej tematyki patos. Dominuje zaciekawienie niemożnością udziału, którą przynosi śmierć. Środkiem zastępczym poznania staje się właśnie niewspółobecność, czyli w tym przypadku metoda egzotopicznego projektowania wspólnoty z umarlymi, ,,patrzenia na siebie zamkniętymi oczami, mówienia zamkniętymi ustami” (MS, s. 16), wyobrażania ich sobie, szukania śladów, sprawdzania symptomów i „,form dojścia”, wymyślania sposobów reprezentacji tych, którzy „,narażeni na nieobecność swoją zewsząd, w każdej chwili” (MS, s. 46).

Rozpatrując cały dorobek Szymborskiej, można zauważyć, że strategie uobecniania, które w wierszach objawiają się jako ślady lub symptomy, przybierają zasadniczo kilka postaci: wyobrażeń, odpomnień i domniemań. Wyobrażenia opierają się zazwyczaj na postrzeganiu danych elementów rzeczywistości - najczęściej organicznego środowiska - jako mimowolnych świadków śmierci, a dobrymi tego przykładami są wiersze Niebo, Wypadek drogowy i Chmury: „Nad całym Twoim życiem / i moim, jeszcze nie całym, / paradują w przepychu jak paradowały" (C, s. 10). Odpomnienia są z kolei niekoniecznie świadomymi reminiscencjami umarłych objawiających się bohaterce dzięki fotografiom (np. Portret z pamięci, Negatyw); w przypadkowych postrzeżeniach i skojarzeniach (np. Listy umartych i Myśli nawiedzajace mnie na ruchliwych ulicach) oraz we śnie (np. w utworach Stuchawka, Konszachty z umartymi, Sen i Każdemu kiedyś). Z kolei domniemania są próbą pomyślenia trybu funkcjonowania, który przypada po życiu (,zmarli zajęci tym, do czego ich przymusza nieobecność"), oraz dociekania, gdzie fizycznie znajdują się szczątki ,jakichś poległych dwieście wieków temu, pięć wieków temu i pół wieku temu" (T, s. 9), co jest jawnym pogłosem poszukiwań z debiutanckich utworów Szymborskiej, gdy mowa była o „grobie, który może być wszędzie [...] nie wolno deptać ziemi” (CP, s. 35). Motyw skrwawionych „polskich równin” (CP, s. 44) i ,grobów masowych" (W, s. 22) powraca stale od pierwszego do ostatniego tomu poetki i wskazuje być może na jedną z przyczyn jej uwrażliwienia na obieg materii w środowisku oraz uważność wobec krajobrazów i tych przestrzeni, które autorka określa jako „nic, co można by nazwać miejscem" (W, s. 16).

Bywa też tak, że Szymborska wykorzystuje chwyty retoryczne ze swego debiutu w późniejszych utworach, zacierając pierwotne konteksty. Niekiedy utrzymany zostaje ton elegijny, ale zmienia się adresat wiersza. Wyrazistym przykładem jest współbrzmienie Janka Muzykanta i Powrotu żalu z lat czterdziestych, gdy Szymborska opłakiwała bliskiego poległego, oraz Pożegnania widoku z tomu Koniec i początek, napisanego po śmierci Kornela Filipowicza. W pierwszym przypadku mowa o „Nieśmiałej, młodej, lepkiej zieleni liści”, którą bohaterka „Chciałaby zrywać, deptać, ranić. / Za jej bezwstyd - że pulsuje słońcem, / że nie wie, co to jest czekanie” (CP, s. 34), oraz o „Słońcu 
pierwszym od wielu miesięcy", co wzmocnione zostaje zobowiązaniem wobec zmarłego:

Nie rozpoznać mi tego lasu,

nie szukać znaku po niebie.

Niebo i las ściegami salw

na śmierć zeszyto.

[...]

Chwilą błahszą niż pył,

bez przeczuć (wina i kara)

przeżyłam cię - nie wybaczaj -

jak dziecko we śnie. Jak owad (CP, s. 67).

W drugim, lepiej znanym przypadku zmienia się postawa mówiącej, ale ton, metafory, sceneria i niektóre ,rekwizyty” są analogiczne; bohaterka deklaruje:

Nie mam żalu do wiosny,

że znowu nastała.

$[\ldots]$

Rozumiem, że mój smutek

nie wstrzyma zieleni.

[...]

Na jedno się nie godzę. Na swój powrót tam.

[...]

Na tyle Cię przeżyłam

i tylko na tyle,

żeby myśleć z daleka (KP, s. 22-23).

Wspólnym polem niespełnionego debiutu i bardziej dojrzałej twórczości Szymborskiej jest zatem cudza, bardzo określona, „bliska” nieobecność - po wielekroć werbalizowana, majacząca na styku biografii i literatury, przybierająca postać figur nieobecności. Te figury wraz z upływem czasu, w toku wydarzania się życia i wydawania kolejnych tomów nabierają samodzielności, zacierają pierwotny kontekst i zaczynają funkcjonować na nowych prawach. Niekiedy echa dialogowania z poległym, nawoływania do powrotu i ukazywania mu atutów życia, które wydarza się pod jego nieobecność (np. w wierszach List na Zachód, Linia życia i Szczyt: ,jest środa, abecadło i chleb” (PC, s. 56), odnaleźć można w zgoła nieoczekiwanych kontekstach, jak choćby w „wołaniu do Yeti” z Nie odbytej wyprawy w Himalaje: „Yeti, niżej jest śro$\mathrm{da}$, abecadło, chleb. [...] Yeti, nie tylko zbrodnie są u nas możliwe. Yeti, nie wszystkie słowa skazują na śmierć. [...] zastanów się, wróć!”). Kiedy indziej funkcję „nieobecnego”, czyli tego, co niepoznawalne, przejmują rośliny, kamień czy ziarnko piasku, do których uparcie przemawia bohaterka (Milczenie roślin, Rozmowa z kamieniem, Widok z ziarnkiem piasku). Wydaje się, że ćwiczone od okupacji i debiutanckich wierszy metody wczucia przyczyniły się 
do ukształtowania tak charakterystycznej dla poezji Szymborskiej uważności i umiejętności egzotopicznego mnożenia odmiennych perspektyw.

Wielce prawdopodobne, że postać „wielkiego nieobecnego" - poległego intensywnie przywoływanego w pierwszych utworach - staje się dla Szymborskiej prototypem inności, której nie sposób zrozumieć i która prowokuje do ponawiania prób przekroczenia własnej perspektywy poznawczej. Być może tamto doświadczenie z młodości, doświadczenie utraty, faktycznie przyczyniło się do późniejszych wysiłków tekstowego oswajania tego, co obce i nieludzkie, konstruowania poetyki dialogicznej czy wręcz polifonicznej, opracowywania poetyckich figur nieobecności i poszukiwania sposobów reprezentacji. Niewątpliwie uwrażliwienie na formy (nie)obecności otworzyło twórczość Szymborskiej na różne, wcale nieoczywiste postaci i byty, których opis - dzięki praktykowaniu metody niewspółobecności - pozwala zarazem na zachowanie osobności, jak i przekroczenie anonimowości, nastrojenie uwagi, przybliżenie danego zjawiska w jego poszczególności. Właśnie napięcie między odmiennością i niemożnością poznania, obecnością i jej brakiem oraz bliskością i potrzebą zdystansowania stanowi główny problem, a zarazem mechanizm napędzający pisanie Szymborskiej. Nieobecność umarłych to podstawowe, ale nie jedyne wyzwanie dla egzotopicznego wyobrażenia. W pewnym momencie zresztą owo napięcie zostaje zniwelowane; autorka, głosząc pochwałę ,świata nie z tego świata” (W, s. 22), stwierdza: „wystarczy”, zbliża się do tego, co „poza zasięgiem naszej obecności” (MS, s. 42), a jedne z ostatnich słów, które zapisuje, brzmią: ,ale cóż, muszę wracać / moja poezja karmi się tylko tęsknotą, a żeby tęsknić, trzeba być z daleka” (W, s. 53). W tym wyznaniu zawiera się być może zasadnicza wskazówka do rozumienia niejednoznaczności dzieła Szymborskiej, które nie jest przecież wyłącznie racjonalistyczną grą paradoksów ani mową uczuć, ale myśleniem afektywnym, poezją intelektualnej nostalgii, poszukiwaniem równowagi między bliskością i oddaleniem, które pobudza tęsknotę.

\section{Bibliografia}

Bachtin M., Dialog, język, literatura, red. E. Czaplejewicz, E. Kasperski, Warszawa 1983.

Balbus S., Wszelki wypadek [w:] Radość czytania Szymborskiej. Wybór tekstów krytycznych, red. S. Balbus, D. Wojda, Kraków 1996.

Bielik-Robson A., Miłość mocna jak śmierć. Przyczynek do innej filozofii skończoności, ,Teksty Drugie” 2013, nr 6.

Bikont A., Szczęsna J., Wisławy Szymborskiej pamiatkowe rupiecie, przyjaciele i sny, Warszawa 2003.

Eliot T.S., Poeci metafizyczni [w:] Szkice literackie, red. W. Chwalewik, przeł. H. Pręczkowska, M. Żurowski, W. Chwalewik, Warszawa 1963. 
Eliot T.S., Tradycja i talent indywidualny [w:] Szkice literackie, red. W. Chwalewik, przeł. H. Pręczkowska, M. Żurowski, W. Chwalewik, Warszawa 1963.

Kurek J., Zmierzch natchnienia, „Europa” 1930, nr 7.

Legeżyńska A., Wisława Szymborska. Czytani dzisiaj, Poznań, 2010.

Ligęza W., O poezji Wisławy Szymborskiej. Świat w stanie korekty, Kraków 2002.

Łukasiewicz J., Wiersz wewnatrz gazety, „Teksty Drugie” 1991, nr 4.

Małochleb P., Świat po bajce jest siny, czyli Szymborska po wojnie, http://www.ksiazkinaostro.pl/swiat-bajce-siny-czyli-szymborska-wojnie/ [dostęp: 21.02.2017].

Massumi B., Autonomia afektu, przeł. A. Lipszyc, „Teksty Drugie” 2013, nr 6.

Neuger L., W otchtani. Próba lektury „Końca i początku” Wisławy Szymborskiej [w:] idem, Pomysty do interpretacji. Studia o literaturze polskiej, Kraków 1997.

Nycz R., Afektywne manifesty, „Teksty Drugie” 2014, nr 1.

Nyczek T., 22 x Szymborska, Poznań 1997.

Szczęsna J., „Pisałam wiersze, piszę wiersze i mam zamiar pisać wiersze” [w:] W. Szymborska, Czarna piosenka, Kraków 2014.

Szkłowski W., Wskrzeszenie słowa [w:] Rosyjska szkoła stylistyki. Wybór tekstów, red. M.R. Mayenowa, Z. Saloni, Warszawa 1970.

Szymborska W., Chwila, Kraków 2002.

Szymborska W., Czarna piosenka, Kraków 2014.

Szymborska W., Dwukropek, Kraków 2005.

Szymborska W., Koniec i początek, Poznań 1993.

Szymborska W., Ludzie na moście, Warszawa 1986.

Szymborska W., Miłość szczęśliwa i inne wiersze, Kraków 2007.

Szymborska W., Sto pociech, Warszawa 1967.

Szymborska W., Tutaj, Kraków 2009.

Szymborska W., Wielka liczba, Warszawa 1976.

Szymborska W., Wszelki wypadek, Warszawa 1972.

Szymborska W., Wszystkie lektury nadobowiązowe, Kraków 2015.

Szymborska W., Wystarczy, Kraków 2011.

Szymborska W., Zmysł udziału, Kraków 2006.

Todorov T., Antropologia filozoficzna, przeł. J. Stankiewicz [w:] M. Bachtin, Dialog, język, literatura, red. E. Czaplejewicz, E. Kasperski, Warszawa 1983.

Zarzycka A., Rewolucja Szymborskiej 1945-1947. O wczesnej twórczości na tle epoki, Poznań 2010. 